\title{
Widest geographic distribution of a shallow and mesophotic antipatharian coral (Anthozoa: Hexacorallia): Antipathes grandis VERRILL, 1928 - confirmed by morphometric and molecular analyses
}

\author{
Erika Gress ${ }^{1,2^{*}}$, Dennis M. Opresko ${ }^{3}$, Mercer R. Brugler ${ }^{4,5}$, Daniel Wagner ${ }^{6}$, Igor Eeckhaut ${ }^{7,8}$ and Lucas Terrana ${ }^{7,8}$
}

\begin{abstract}
We provide the first record of the shallow and mesophotic ( $<150 \mathrm{~m}$ depth) antipatharian coral Antipathes grandis VERRILL, 1928 from the Indian Ocean. First described from Hawaii, A. grandis was recently found on a mesophotic coral reef in SW Madagascar. Its identity was confirmed by means of morphological and molecular analyses (cytochrome c oxidase subunit I). These findings not only expand our knowledge of the potential geographic range of antipatharian corals, but also challenge the belief that only deep-sea (> $200 \mathrm{~m}$ depth) benthic taxa have such wide geographic distributions.
\end{abstract}

Keywords: Black coral, Geographic range, Madagascar, Hawaii, Indian Ocean, Antipatharia

\section{Introduction}

Corals in the order Antipatharia MILNE-EDWARDS \& HAIME, 1857 (Anthozoa: Hexacorallia) - commonly known as black corals - inhabit all oceans at depths ranging from $2 \mathrm{~m}$ down to $8600 \mathrm{~m}$ (Roberts et al. 2009; Wagner et al. 2012). Around 273 antipatharian species, within 45 genera and 7 families, have been described. Despite their importance as habitat providers on reefs at all depths (Love et al. 2007; Tazioli et al. 2007; Suarez et al. 2015; Gress and Andradi-Brown 2018), ecological studies of these corals are still very limited. Moreover, long-term ecological studies are rare. Exceptions include the ecological studies dedicated to Antipathes grandis, which was the first antipatharian species described from Hawaii (Verrill 1928).

\footnotetext{
*Correspondence: gresserika@gmail.com; erika@nektonmission.org 'ARC Centre of Excellence for Coral Reef Studies, James Cook University, Townsville, Australia

${ }^{2}$ Nekton Foundation, Oxford, England

Full list of author information is available at the end of the article
}

Vast aggregations of A. grandis (VERRILL, 1928) were first documented in the late 1960s on mesophotic reefs off the western side of Maui, Hawaii (Grigg 1964, 1965, 1984, 2001). The arborescent colonies of $A$. grandis and Antipathes griggi (Opresko 2009) have been harvested for their skeleton to support the black coral jewellery industry since their discovery in Hawaii (Grigg 1984, 2001; Montgomery and France 2006; Wagner et al. 2010). This commercial exploitation of antipatharian corals has been the impetus for ecological studies on these two species for several decades in Hawaii (Grigg 1964, 1965, 1984, 1993, 2001; Kahng and Grigg 2005; Wagner et al. 2010, 2017). The harvesting was presumed to be sustainable (Grigg 1984, 1993, 2001), although the latest findings demonstrate that the populations were declining after several decades of exploitation (Grigg 2004; Montgomery and France 2006). These ecological studies, however, are some of the lengthiest and most detailed ones conducted on any antipatharian species to date.

(c) The Author(s). 2020 Open Access This article is licensed under a Creative Commons Attribution 4.0 International License, which permits use, sharing, adaptation, distribution and reproduction in any medium or format, as long as you give

appropriate credit to the original author(s) and the source, provide a link to the Creative Commons licence, and indicate if changes were made. The images or other third party material in this article are included in the article's Creative Commons licence, unless indicated otherwise in a credit line to the material. If material is not included in the article's Creative Commons licence and your intended use is not permitted by statutory regulation or exceeds the permitted use, you will need to obtain permission directly from the copyright holder. To view a copy of this licence, visit http://creativecommons.org/licenses/by/4.0/ 
The most recent study of $A$. grandis (Wagner et al. 2010) re-examined and re-described the holotype of this species, providing detailed photomicrographs of its spines for the first time. The study included morphometric and molecular analyses of 34 colonies of $A$. grandis, and incorporated in situ observations that enabled differentiation between $A$. grandis and its sympatric congener A. griggi. Importantly, it documented an array of morphological features that support the taxonomic identification of these two species. Moreover, the mitochondrial and nuclear DNA sequence data from this study provided insights into useful genetic markers that can help differentiate among antipatharian taxa of the family Antipathidae.

Detailed morphological features of $A$. grandis were reviewed by Wagner et al. (2010) and summarised in Wagner (2015). Overall, the depth range of this species, in Hawaii, spans from $27 \mathrm{~m}$ to $127 \mathrm{~m}$, and three colour morphotypes have been reported: white, pale-red and red. A. grandis forms arborescent colonies that can reach over $3 \mathrm{~m}$ in height with long branches disposed irregularly in all sides of the corallum (Fig. 1). Terminal branchlets can reach $10 \mathrm{~cm}$ in length, with a maximum branch diameter of $0.273 \mathrm{~mm}$ without tissue. Spines on the terminal branchlets are conical, non-bifurcated and covered with circular to elongated papillae from the distal end down to about three-quarters of the distance to the base (Wagner et al. 2010; Wagner 2015; Fig. 2). The height of the spines on the terminal branchlets, as well as polyp density and transverse diameter, are summarised in Table 1.

Unconfirmed reports of $A$. grandis from China (Zou and Zhou 1984) and Indonesia (Tazioli et al. 2007) exist. Also, specimens collected in the Marshall Islands, Palau and Tonga - deposited in the National Museum of Natural History (NMNH), Smithsonian Institution - were provisionally identified as $A$. cf. grandis. Verification of their identity by means of morphological and molecular analyses are not available and were beyond the scope of our study. Here, we present results of taxonomic and genetic analyses conducted on two antipatharian specimens collected off the south-western shore of Madagascar, where other $>20$ antipatharian species have been documented (Pichon 1978; Terrana et al. 2020). Morphological and molecular results support the identification of the red and white morphotype as A. grandis. Having been originally described from Hawaii, this first report of $A$. grandis from the Western Indian Ocean represents a considerable range expansion of this species.

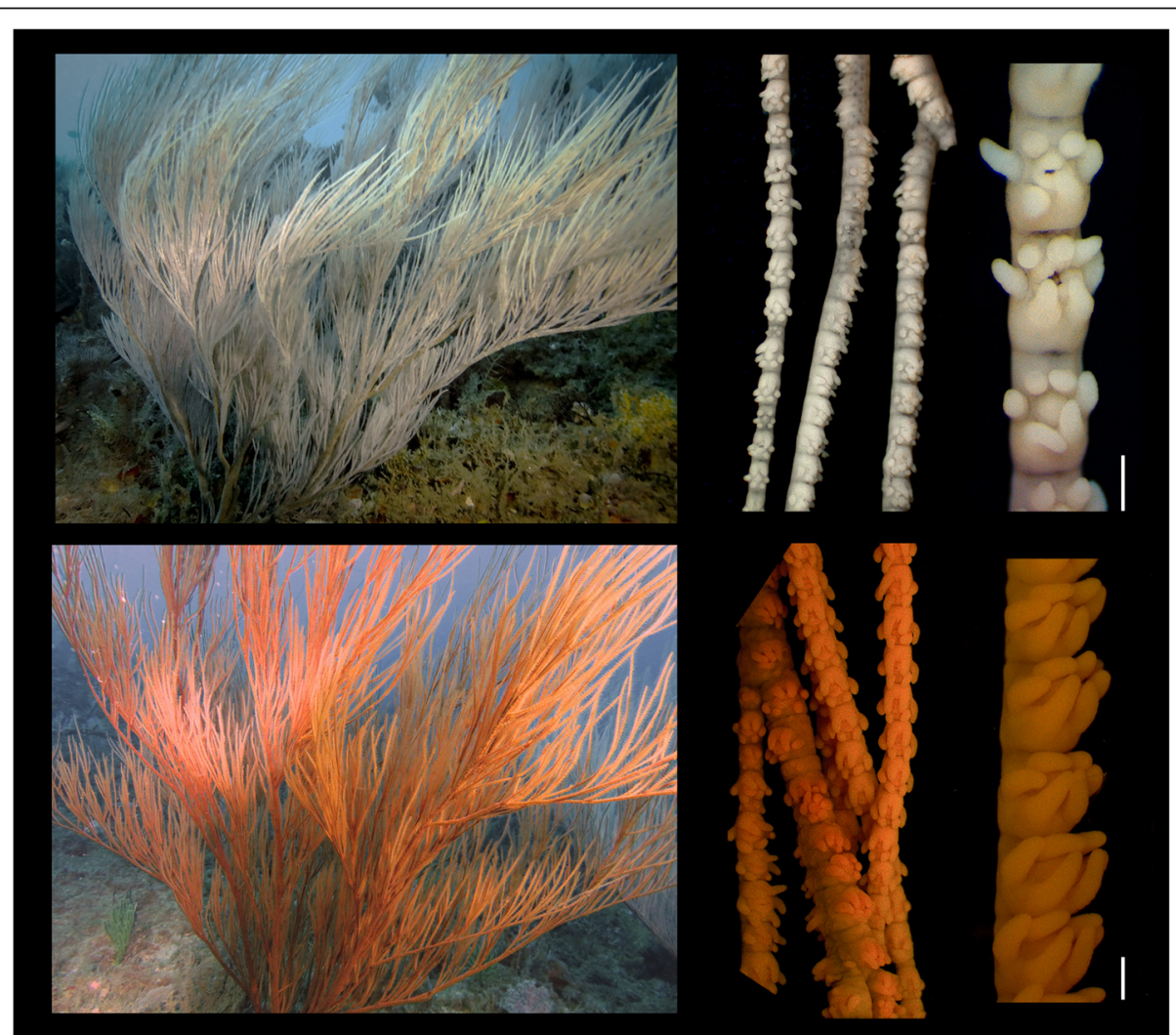

Fig. 1 A. grandis colonies from SW Madagascar examined in this study. White morphotype (top) and red morphotype (bottom). From left to right: full colonies, branches, and polyps. Scale bars of polyp images $=0.5 \mathrm{~mm}$ 


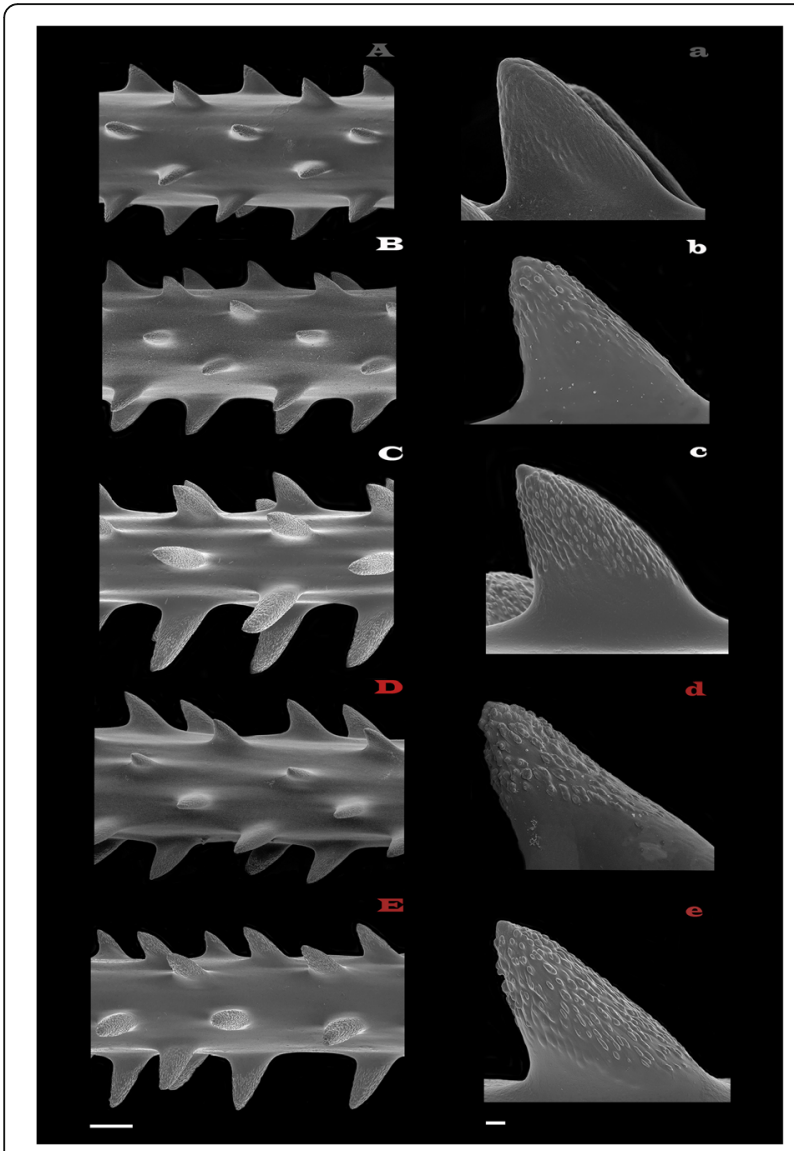

Fig. 2 Scanning electron micrographs of terminal branchlets and abpolypar spines. Terminal branchlets represented by capital letters, with their respective lower case indicating the close-up of an abpolypar spine. From top down: A. grandis holotype - unknown colour $(\mathbf{A}, \mathbf{a})$; A. grandis from Hawaii - white $(\mathbf{B}, \mathbf{b})$; A. grandis from Madagascar - white $(\mathbf{C}, \mathbf{C}) ; A$ grandis from Hawaii - red (D, d); A. grandis from Madagascar - red (E,e). Terminal branchlets from the Malagasy specimens $(\mathbf{C}, \mathbf{E})$ clearly show polypar spines at the bottom side of the branchlet. Indicative scale bar of terminal branchlets $=100 \mu \mathrm{m}$. Indicative scale bar of spines $=10 \mu \mathrm{m}$

\section{Materials and methods Sample collection}

Two branching antipatharian colonies each about $1.5 \mathrm{~m}$ wide - a white and a red colour morphotype (Royal Belgian Institute of Natural Sciences in Brussels, INV.131346) - were sampled in December 2018 at $40 \mathrm{~m}$ depth on a mesophotic coral reef located off the northern part of the Great Reef of Toliara (GRT), in SW Madagascar $\left(23^{\circ} 21.345^{\prime} \mathrm{S}, 43^{\circ} 36.348^{\prime} \mathrm{E}\right)$. Each $20 \mathrm{~cm}$ sample was divided into two sections. For molecular analyses, $5 \mathrm{~cm}$ subsamples were preserved in $100 \%$ ethanol, whereas for morphological examination, $15 \mathrm{~cm}$ subsamples were preserved in $75 \%$ ethanol.

\section{Morphometrics}

From each of the samples preserved in $75 \%$ ethanol, three sub-samples were cut from the terminal branchlets. The six sub-samples were dried in a criticalpoint dryer using $\mathrm{CO}_{2}$ as the transition fluid (Agar Scientific Ltd.) before being mounted on aluminium stubs and coated with gold in a JFC-1100E (JEOL) sputter coater. Samples were observed and photographed with a JEOL (JSM-7200F) scanning electron microscope (SEM). Photographs were further analysed with the software Image J (Schneider, et al. 2012) to obtain information on the height and morphology of the polypar and abpolypar spines and the diameter of the terminal branchlets. The transverse diameter of the polyps was determined using images taken with a Leica camera (MC190HD) and analysed in the software Image J. The number of colonies examined $(N)$, the number of measurements taken of each feature $(n)$, the protocols followed to conduct morphometrics and overall results are in Table 1.

\section{Molecular analyses}

Total genomic DNA of each sample was extracted using a QIAGEN DNeasy Blood \& Tissue Kit following the manufacturer's protocol. The concentration and quality of DNA were examined at $260 \mathrm{~nm}$ using a spectrophotometer (DeNovix). With regard to mitochondrial DNA, the cytochrome c oxidase subunit I $(\operatorname{cox} 1)$ - that contains the 'Barcode of Life' - and the intergeneric region (IGR), located between cox 1 and the cytochrome c oxidase subunit III ( $\operatorname{cox} 3$ ), were amplified using the primers CO3anti3509F ( $5^{\prime}$ TGG TAT TGG CAT TTT GTG GAT GT 3') and CO1 gen4446R (5' CCA TAA ATA GTG GCC AAC CAA CTA $3^{\prime}$ ) (Wagner et al. 2010). Concerning nuclear ribosomal DNA (rDNA), the first internal transcribed spacer (ITS1) was amplified using the primers F18S1 (5' CGATYGAAYGGTTTAG TGAGGC 3') and ITSc1 (5' CATTTGCGTTCAAAGA TTCG 3') (Flot et al. 2011). Polymerase chain reaction (PCR) amplifications were carried out in $50 \mu \mathrm{L}$ reaction mixes using Taq Red'y'StarMix (Eurogentec) - using an annealing temperature of $51{ }^{\circ} \mathrm{C}$ with an extension at $72{ }^{\circ} \mathrm{C}$ for $120 \mathrm{~s}$ for $\operatorname{cox} 1$ - and an annealing temperature of $52^{\circ} \mathrm{C}$ with an extension at $72{ }^{\circ} \mathrm{C}$ for $30 \mathrm{~s}$ for ITS1. The presence of PCR products was visually checked in a $2 \%$ agarose gel in Tris-Borate-EDTA buffer. PCR products were Sanger-sequenced in both directions (Eurofins Genomics). Sequences are publicly available in GenBank. Accession numbers (Acc. No) of red morphotype: MT457945, MT444761; Acc. No. of white morphotype: MT457944, MT444760; IGR-cox1 and ITS1 regions, respectively.

\section{Phylogenetic analyses}

Newly-generated mitochondrial IGR-cox1 sequences of each colour morphotype from Madagascar were added to the cox3-IGR-cox 1 dataset presented in Fig. 5 in Brugler et al. (2013). Given that cox3 data were not obtained 
Table 1 Summary of morphometric results of the A. grandis holotype, the 34 samples examined from Hawaii (Wagner et al. 2010, including analysis of raw data not previously published), and the samples examined from Madagascar in this study - with a focus on most informative features. The number of colonies examined or samples of individual colonies $(N)$, and the number of measurements taken of each feature $(n)$ is specified. Measurement protocols apply for the specimens from Madagascar $(\mathbf{M})$, since measurements of the Hawaiian samples were taken randomly

\begin{tabular}{|c|c|c|c|c|c|c|c|}
\hline & \multirow{2}{*}{$\begin{array}{l}\text { HOLOTYPE } \\
\text { Unknown } \\
\text { colour }\end{array}$} & \multicolumn{3}{|l|}{ HAWAII } & \multicolumn{2}{|c|}{ MADAGASCAR } & \multirow[t]{2}{*}{ MEASUREMENTS PROTOCOLS } \\
\hline & & $\begin{array}{l}\text { Pale } \\
\text { Red }\end{array}$ & Red & White & Red & White & \\
\hline COLONIES & $N=1$ & $N=5$ & $N=25$ & $N=4$ & $N=1$ & $N=1$ & \\
\hline Colony height (m) & 1.28 & $>3$ & $>3$ & $>3$ & $\sim 2$ & $\sim 2$ & \\
\hline Bathymetric range (m) & & $88-127$ & $27-127$ & $88-127$ & $40-?$ & $30-?$ & \\
\hline BRANCHLETS & $n=?$ & $n=24$ & $n=100$ & $n=20$ & $n=10$ & $n=10$ & \\
\hline $\begin{array}{l}\text { Longest terminal branchlet } \\
\text { length }(\mathrm{mm})\end{array}$ & & 100 & 100 & 100 & 85 & 98 & \\
\hline $\begin{array}{l}\text { Terminal branchlet diameter } \\
\text { range }(\mathrm{mm})\end{array}$ & & $\begin{array}{l}0.090- \\
0.227\end{array}$ & $\begin{array}{l}0.092- \\
0.273\end{array}$ & $\begin{array}{l}0.124- \\
0.219\end{array}$ & $\begin{array}{l}0.180- \\
0.260\end{array}$ & $\begin{array}{l}0.168- \\
0.192\end{array}$ & $\begin{array}{l}\text { Taken at the middle point of the } \\
\text { branchlets without spines }(\mathbf{M})\end{array}$ \\
\hline SPINES & $n=100$ & $n=120$ & $n=490$ & $n=100$ & $n=50$ & $n=50$ & \\
\hline $\begin{array}{l}\text { Polypar spines height range } \\
\text { (mm) }\end{array}$ & $0.050-0.150$ & $\begin{array}{l}0.049- \\
0.123\end{array}$ & $\begin{array}{l}0.049- \\
0.168\end{array}$ & $\begin{array}{l}0.063- \\
0.118\end{array}$ & $\begin{array}{l}0.111- \\
0.138\end{array}$ & $\begin{array}{l}0.091- \\
0.161\end{array}$ & $\begin{array}{l}\text { Distance between the apex and the } \\
\text { centre of the base of the same spine - }\end{array}$ \\
\hline $\begin{array}{l}\text { Abpolypar spines height range } \\
(\mathrm{mm})\end{array}$ & $0.045-0.125$ & $\begin{array}{l}0.031- \\
0.90\end{array}$ & $\begin{array}{l}0.033- \\
0.110\end{array}$ & $\begin{array}{l}0.039- \\
0.083\end{array}$ & $\begin{array}{l}0.068- \\
0.097\end{array}$ & $\begin{array}{l}0.069- \\
0.100\end{array}$ & from terminal branchlets middle point $(\mathbf{M})$ \\
\hline POLYPS & $n=20$ & $n=26$ & $n=64$ & $n=20$ & $n=10$ & $n=10$ & \\
\hline Density of polyps per $\mathrm{cm}$ - range & $7-10$ & $6-11$ & $7-11$ & $7-13$ & $9-13$ & $9-13$ & $\begin{array}{l}\text { Counted from the middle part of the } \\
\text { terminal branchlets }(M)\end{array}$ \\
\hline $\begin{array}{l}\text { Transverse diameter of polyps - } \\
\text { range (mm) }\end{array}$ & $\begin{array}{l}0.69-0.87 \text { dried } \\
\text { state }\end{array}$ & $\begin{array}{l}0.35- \\
1.23\end{array}$ & $\begin{array}{l}0.45- \\
1.18\end{array}$ & $\begin{array}{l}0.37- \\
1.23\end{array}$ & $\begin{array}{l}0.71- \\
1.00\end{array}$ & $\begin{array}{l}0.82- \\
1.03\end{array}$ & $\begin{array}{l}\text { Avoiding measuring from areas with } \\
\text { juvenile polyps }(\boldsymbol{M})\end{array}$ \\
\hline
\end{tabular}

for the Malagasy specimens, and difficulty aligning the intergenic region with outgroups, these two regions were removed from the alignment prior to analysis. The final data set consisted of 58 taxa and 797 sites. Multiple sequence alignment was determined with MAFFT (Multiple Alignment using Fast Fourier Transform) v7 online (http://mafft.cbrc.jp/alignment/server/) using the following parameters: strategy: L-INS-i, gap open: 1.53, gap offset: 0.00 (Katoh et al. 2002, 2005; alignment available upon request to MRB). The Akaike information criterion (AIC) was implemented within jModelTest v2.1.10 (Darriba et al. 2012) to determine the appropriate evolutionary model and corresponding parameters [p-inv: 0.5400, gamma shape: 1.2640, freqA: 0.2374, freqC: 0.2047, freqG: 0.1983, freqT: 0.3596, (AC): 1.7415, (AG) \& (CT): 8.5935, (AT): 1.1501, (CG): 0.2904, (GT): 1.0000] for the data set (number of candidate models: 88; number of substitution schemes: 11; base tree for likelihood calculations: BioNJ). TVM + I + G was selected by AIC as the best model. A maximum likelihood (ML) based phylogenetic tree was built using the command-line version of PhyML v3.1 (Guindon et al. 2010). PhyML parameters included a tree topology search consisting of the best of NNIs and SPRs, a BioNJ starting tree, and 1000 bootstrap replicates.

\section{Results and discussion}

Results of the morphological examinations of the two Malagasy A. grandis specimens are summarised in Table 1. In addition, raw morphometric data from the Hawaiian specimens studied by Wagner et al. (2010) were reanalysed to present results for each colour morphotype. However, the number of measurements of each feature $(n)$ and number of colonies examined $(N)$ differ considerably between studies - and within each colour morphotype in Wagner et al. (2010) (Table 1) - to allow for a strict comparison. In addition, the measurement protocols differ in some instances. Protocols followed for the Malagasy specimens (this study) were designed to ensure consistency in the measurements and target the most informative areas of the specimens. Regardless, all morphometric results from the Malagasy specimens fall within the ranges reported in the intraspecific study from Hawaii independently of the colouration (Table 1). For instance, the height of polypar spines ranged from 0.091 to $0.161 \mathrm{~mm}$ in the Malagasy samples, while they ranged from 0.049 to $0.168 \mathrm{~mm}$ in samples from Hawaii. The wider ranges reported in the Hawaiian population might be due to the larger number of specimens examined ( $N=34$ vs. $N=2)$, and the fact that the measurements might not have been taken at the same relative 
locations along the terminal branchlets in the two studies.

Only two colour morphotypes were observed in Madagascar: red and white (Fig. 1). Colonies were observed between $30 \mathrm{~m}$ and $40 \mathrm{~m}$ depth, although the maximum depth range remains unknown. In Hawaii, the white and pale red morphotypes were exclusively observed between $88 \mathrm{~m}$ and $127 \mathrm{~m}$. Depth range of the Hawaiian red morphotype was $27 \mathrm{~m}$ to $127 \mathrm{~m}$. Despite the minimum depth range discrepancy and other differences in the ranges of some of the morphometrics (see Table 1), all colour morphotypes in Hawaii (i.e. all 34 colonies) were taxonomically determined as being the same species. The taxonomic identification was supported by the molecular analysis which showed no variation within the mitochondrial cox3-IGR-cox1 region (Wagner et al. 2010). Features of polypar and abpolypar spines on terminal branchlets - one of the most informative characteristics (Opresko 1974) - did not differ from the Hawaiian specimens (Fig. 2). Spines of both colour morphotypes from Madagascar showed slight variations in the coverage and thickness of papillae (Fig. 2). This variation was also reported for the spines on the holotype and the other Hawaiian A. grandis specimens (Wagner et al. 2010, Fig. 2). Therefore, based on the morphological examination, both colour morphotypes could be identified as $A$. grandis.

Synonymous substitution rates in anthozoan cox 1 mtDNA were shown to be 50-100 times slower than rates for other multicellular animals (Hellberg 2006). Molecular sequence evolution within antipatharian mtDNA was shown to be at least 2.3 times slower than corals in the subclass Octocorallia (Brugler et al. 2013). Therefore, minor variations in the mtDNA might represent a distinct species based on the molecular evolution of antipatharians. Of the suite of mtDNA markers that are typically sequenced for antipatharians phylogenetics (trnW-IGR- nad2, nad5-IGR-nad1, and cox3-IGR-cox1), mitochondrial cox3-IGR-cox1 consistently reveals a larger number of unique haplotypes when compared to the other mtDNA regions (Brugler et al. 2013). The IGR-cox1 region sequenced from the Malagasy white morphotype differed from the Hawaiian A. grandis at a single position (a purine transition) across $820 \mathrm{bp}$, which is captured in the ML phylogenetic tree (Fig. 3). However, morphological characteristics align this white morphotype with other $A$. grandis samples examined (Table 1, Fig. 2). Confirmation of its taxonomic identity will necessitate examination of other individuals. For instance, sequencing additional mtDNA markers that have recently been proposed to be more variable (nad4; Barrett et al. 2020), and application of next generation sequencing techniques (e.g., ultraconserved elements and exon loci; Quattrini et al. 2018). The red morphotype from Madagascar was genetically identical to the Hawaiian A. grandis across 817 bp of IGR-cox1, which validates its identification as $A$. grandis. Nuclear ITS1 is a region that has been found to be highly variable within a single individual in most multicellular animals. Within antipatharians, ITS1 appears to evolve even slower than mtDNA (Brugler et al. 2013). The ITS1 chromatograms of the red (452 bp) and white (421 bp) morphotypes from Madagascar contained instances of double peaks in a single position. As previously shown (Wagner et al. 2010), after resolving such ambiguities, ITS1 sequences revealed no variation beyond that of mitochondrial IGR-coxl.

\section{Conclusion}

Based on morphological similarities with the holotype and the Hawaiian specimens, as well as IGR-cox1 sequence alignments, the red morphotype from Madagascar was identified as $A$. grandis. This represents the first record of this species from the Indian Ocean, and the widest geographic distribution of a shallow and mesophotic antipatharian confirmed by morphometric

$$
\begin{aligned}
& \text { Aphanipathes verticillata mauiensis P42041 }
\end{aligned}
$$

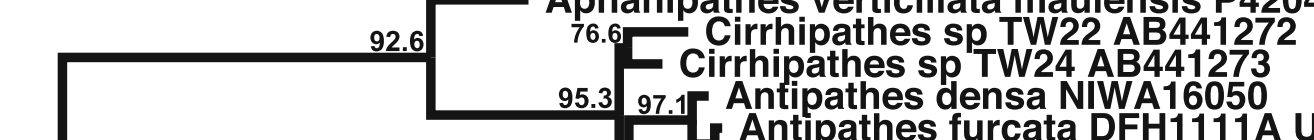

$$
\begin{aligned}
& \text { Antipathes furcata DFH1111 A USNM1116474 } \\
& 71.9 \text { Antipathes curvata USNM1015453 } \\
& \text { 71.9 Antipathes grandis - RED Malagasy morphotype } \\
& \text { 95.8 Antipathes grandis - WHITE Malagasy morphotype } \\
& \text { Antipathes grandis DO1 - Hawaii } \\
& \text { 87.0 Stichopathes cf Occidentalis SED8045 } \\
& \text { Antipathes griggi P420027 } \\
& \text { Antipathes caribbeana USNM1122627 } \\
& \text { Elatopathes abietina DFH116A USNM1116469 }
\end{aligned}
$$

0.2

Fig. 3 Maximum likelihood (ML) based phylogenetic tree built with the newly-generated IGR-coxI sequences of each colour morphotype from Madagascar, andthe cox3-IGR-cox1 dataset presented in Fig. 5 in Brugler et al. (2013) 
and molecular analyses. Based on morphometric examination alone, the white morphotype was provisionally assigned as $A$. grandis. However, because of the single substitution in the IGR-cox1 sequence alignment (820 bp), this white colour morphotype requires additional molecular analyses.

\section{Abbreviations}

Acc. No.: Accession number; bp: Base pair; cox1: Cytochrome c oxidase subunit I; cox3: Cytochrome c oxidase subunit III; IGR: Intergeneric region; ML: Maximum likelihood; PCR: Polymerase chain reaction; SEM: Scanning electron microscope; SW: South West

\section{Acknowledgments}

We thank: The Institute of Halieutic and Marine Sciences, Madagascar, for their support. Xavier Pochon, Cawthron Institute, for his advice on protocols on early stages of the molecular analysis. Liz Tynan, James Cook University, for editorial feedback.

\section{Glossary}

- Abpolypar spines: Those on the side of the skeletal axis opposite to the side bearing the polyps; not restricted to the area of each polyp.

- Polypar spines: Those on the side of the axis that bear the polyps; not restricted to the immediate area of each polyp.

- Corallum: term used to describe the skeletal structure of an antipatharian colony.

- Haplotypes: segments of mitochondrial DNA.

- Mitogenome: The complete mitochondrial genome.

- Papillae: small rounded to elongated protuberances on the surface of the spines.

- Terminal branchlets: highest order branches that do not sub-branch.

\section{Authors' contributions}

Conceptualisation: EG. Writing of manuscript and figures preparation: EG. Morphometric analyses: DMO, DW, EG, LT. Molecular analyses: EG. Phylogenetic analyses: MRB. Funding acquisition: IE, LT. All authors contributed to the manuscript revision, read and approved the submitted version.

\section{Funding}

Study funded by the Fonds National de la Recherche Scientifique, Belgium ( $n^{\circ}$ PDR T0083.18) under the 'Conservation Biology of Black Corals' research project co-directed by the University of Mons, the University of Liège, and the Free University of Brussels, in Belgium.

\section{Availability of data and materials}

Sequence data generated in this study were uploaded to NCBI's GenBank Accession numbers are specified in the Material and Methods section. The datasets generated for this study are available on request to the corresponding author.

\section{Competing interests}

We declare that the research was conducted in the absence of any commercial or financial relationships that could be construed as a potential conflict of interest.

\footnotetext{
Author details

${ }^{1}$ ARC Centre of Excellence for Coral Reef Studies, James Cook University, Townsville, Australia. ${ }^{2}$ Nekton Foundation, Oxford, England. ${ }^{3}$ U.S. National Museum of Natural History, Smithsonian Institution, Department of Invertebrate Zoology, Washington, DC, USA. ${ }^{4}$ American Museum of Natural History, Division of Invertebrate Zoology, New York, NY, USA. ${ }^{5}$ Department of Natural Sciences, University of South Carolina Beaufort, Beaufort, SC, USA. ${ }^{6}$ Center for Oceans, Conservation International, Arlington, VA, USA. ${ }^{7}$ Marine Organisms and Biomimetics Laboratory, University of Mons, Mons, Belgium. ${ }^{8}$ Marine Station of Belaza, Institute of Halieutic and Marine Sciences, Toliara, Madagascar.
}

Received: 2 July 2020 Accepted: 25 November 2020

Published online: 09 December 2020

\section{References}

Barrett NJ, Hogan Rl, Allcock AL, et al. Phylogenetics and Mitogenome organisation in Black corals (Anthozoa: Hexacorallia: Antipatharia): an orderwide survey inferred from complete mitochondrial genomes. Front mar Sci. 2020;7. https://doi.org/10.3389/fmars.2020.00440.

Brugler MR, Opresko DM, France SC. The evolutionary history of the order Antipatharia (Cnidaria: Anthozoa: Hexacorallia) as inferred from mitochondrial and nuclear DNA: implications for black coral taxonomy and systematics. Zool J Linnean Soc. 2013;169:312-61. https://doi.org/10.1111/zoj.12060.

Darriba D, Taboada GL, Doallo R, Posada D. JModelTest 2: more models, new heuristics and parallel computing. Nat Methods. 2012;9:772.

Flot JF, Blanchot J, Charpy L, et al. Incongruence between morphotypes and genetically delimited species in the coral genus Stylophora: phenotypic plasticity, morphological convergence, morphological stasis or interspecific hybridization? BMC Ecol. 2011;11. https://doi.org/10.1186/1472-6785-11-22.

Gress E, Andradi-Brown DA. Assessing population changes of historically overexploited black corals (order: Antipatharia) in Cozumel, Mexico. PeerJ. 2018;6. https://doi.org/10.7717/peerj.5129.

Grigg RW. Resource Management of Precious Corals: a review and application to shallow water reef building corals. Mar Ecol. 1984;5:57-74. https://doi.org/10. 1111/j.1439-0485.1984.tb00307.x.

Grigg RW. Ecological studies of black coral in Hawai 'i. Pacific Sci. 1965:244-60.

Grigg RW. A contribution to the biology and ecology of the black coral, Antipathes grandis in Hawaii. M.Sc. Thesis. University of Hawai 'i, Honolulu, Hl; 1964.

Grigg RW. Harvesting impacts and invasion by an alien species decrease estimates of Black coral yield off Maui, Hawai'i. Pacific Sci. 2004;58:1-6. https://doi.org/10.1353/psc.2004.0006.

Grigg RW. Black coral: history of a sustainable fishery in Hawaii. Pacific Sci. 2001; 55:291-9. https://doi.org/10.1353/psc.2001.0022.

Grigg RW. Precious coral fisheries of Hawaii and the U.S. Pacific Islands. Mar Fish Rev. 1993:55:50-60.

Guindon S, Dufayard J-FF, Lefort V, et al. New algorithms and methods to estimate maximum-likelihood phylogenies: assessing the performance of PhyML 3.0. Syst Biol. 2010;59:307-21. https://doi.org/10.1093/sysbio/syq010.

Hellberg ME. No variation and low synonymous substitution rates in coral mtDNA despite high nuclear variation. BMC Evol Biol. 2006;6:24. https://doi. org/10.1186/1471-2148-6-24.

Kahng SE, Grigg RW. Impact of an alien octocoral, Carijoa riisei, on black corals in Hawaii. Coral Reefs. 2005;24:556-62. https://doi.org/10.1007/s00338-005-00260 .

Katoh K, Kuma Kl, Toh H, Miyata T. MAFFT version 5: improvement in accuracy of multiple sequence alignment. Nucleic Acids Res. 2005;33:511-8. https://doi. org/10.1093/nar/gki198.

Katoh K, Misawa K, Kuma Kl, Miyata T. MAFFT: a novel method for rapid multiple sequence alignment based on fast Fourier transform. Nucleic Acids Res. 2002; 30:3059-66. https://doi.org/10.1093/nar/gkf436.

Love MS, Yoklavich MM, Black BA, Andrews AH. Age of black coral (Antipathes dendrochristos) colonies, with notes on associated invertebrate species. Bull Mar Sci. 2007;80:391-9.

Montgomery A, France S. An investigation of the current status of the Hawaiian Black coral fishery using historical and new perspectives. Hawaii: Report. Department of Land and Natural Resources; 2006.

Opresko DM. A study of the classification of the Antipatharia (Coelenterata: Anthozoa) with the redescritions of eleven species; 1974.

Opresko DM. A new name for the Hawaiian Antipatharian coral formerly known as Antipathes dichotoma (Cnidaria: Anthozoa: Antipatharia). Pacific Sci. 2009; 63:277-91. https://doi.org/10.2984/049.063.0209.

Pichon M. Recherches sur les peuplements a dominance d'anthozoaires dans les recifs coralliens de Tulear (Madagascar). Atoll Res Bull Smithson Inst Washingt. 1978;222:1-490.

Quattrini AM, Faircloth BC, Dueñas LF, et al. Universal target-enrichment baits for anthozoan (Cnidaria) phylogenomics: new approaches to long-standing problems. Mol Ecol Resour. 2018;18:281-95. https://doi.org/10.1111/17550998.12736.

Roberts MJ, Wheeler AJ, Freiwald A, Cairns SD. Cold-water corals: The biology and geology of deep-sea coral habitats; 2009. 
Schneider CA, Rasband WS, Eliceiri KW. NIH image to ImageJ: 25 years of image analysis. Nat Methods. 2012;9:671-5.

Suarez HN, Dy DT, Violanda RR. Density of associated macrofauna of black corals (Anthozoa: Antipatharia) in Jagna, Bohol, Central Philippines. Philipp J Sci. 2015;144:107-15

Tazioli S, Bo M, Boyer M, et al. Ecological observations of some common antipatharian corals in the marine park of Bunaken (North Sulawesi, Indonesia). Zool Stud. 2007:46:227-41.

Terrana L, Bo M, Opresko DM, Eeckhaut I. Shallow-water black corals (Cnidaria: Anthozoa: Hexacorallia: Antipatharia) from SW Madagascar; 2020

Verrill AE. Hawaiian shallow water Anthozoa. Bernice P Bish Museum Bull. 1928; 49:3-30. https://doi.org/10.5962/bhl.title.58574.

Wagner D. A taxonomic survey of the shallow-water $(<150 \mathrm{~m})$ black corals (Cnidaria: Antipatharia) of the Hawaiian islands. Front Mar Sci. 2015;2(24):121. https://doi.org/10.3389/fmars.2015.00024.

Wagner D, Brugler MR, Opresko DM, et al. Using morphometrics, in situ observations and genetic characters to distinguish among commercially valuable Hawaiian black coral species; a redescription of Antipathes grandis Verrill, 1928 (Antipatharia: Antipathidae). Invertebr Syst. 2010;24:271-90. https://doi.org/10.1071//S10004.

Wagner D, Luck DG, Toonen RJ. The biology and ecology of Black corals (Cnidaria: Anthozoa: Hexacorallia: Antipatharia). Adv Mar Biol. 2012;63:67-132. https://doi.org/10.1016/B978-0-12-394282-1.00002-8

Wagner D, Opresko D, Montgomery A, Parris F. An update on recent research and Management of Hawaiian Black Corals. In: Hourigan TF, Etnoyer PJ, Cairns S, editors. The state of Deep-Sea coral and sponge ecosystems of the United States report. NOAA technical memorandum NMFS-OHC-4, silver spring; 2017. p. 1-16.

Zou R, Zhou J. Antipatharians from Hong Kong waters with a description of a new species. Asian Mar Biol. 1984;3(2):101-5.

\section{Publisher's Note}

Springer Nature remains neutral with regard to jurisdictional claims in published maps and institutional affiliations.

Ready to submit your research? Choose BMC and benefit from:

- fast, convenient online submission

- thorough peer review by experienced researchers in your field

- rapid publication on acceptance

- support for research data, including large and complex data types

- gold Open Access which fosters wider collaboration and increased citations

- maximum visibility for your research: over $100 \mathrm{M}$ website views per year

At $\mathrm{BMC}$, research is always in progress.

Learn more biomedcentral.com/submissions 